Journal of Social Sciences (COES\&RJ-JSS)

ISSN (E): 2305-9249 ISSN (P): 2305-9494

Publisher: Centre of Excellence for Scientific \& Research Journalism, COES\&RJ LLC Online Publication Date: $1^{\text {st }}$ July 2016

Online Issue: Volume 5, Number 3, July 2016

http://centreofexcellence.net/J/JSS/JSS\%20Mainpage.htm

\title{
The Impact of Intellectual Capital Disclosure on Market Value: An Empirical Study on Jordanian Pharmaceutical Manufacturing Companies Listed in Amman Stock Exchange
}

Dr. Abdelrazaq Faleh Altal

Abstract:

The World Islamic Sciences \& Education University

The aim of this study was to explore the extent to which Jordanian pharmaceutical manufacturing companies disclose information on their intellectual capital components (human capital, structural capital, and relational capital), and its impact on companies' market value, as measured by return on assets and rate of annual trading value. Content examination of annual reports was used to assess the extent of intellectual capital disclosure. The impact of disclosure was analyzed using regression analysis. All public shareholding pharmaceutical manufacturing companies listed in Amman Stock Exchange from 2007 to 2012, which comprised 6 companied, were included in the study. The results revealed that the disclosure of intellectual capital components have a significant impact on companies' market value. Hence, pharmaceutical companies are required to pay more attention to extend their disclosure of intellectual capital elements, and to adopt new strategies that intensify investments in intangible assets.

Keywords:

Intellectual capital disclosure, market value, pharmaceutical companies.

\section{Citation:}

Altal, Dr. Abdrlrazaq Faleh Altal (2016); The Impact of Intellectual Capital Disclosure on Market Value: An Empirical Study on Jordanian Pharmaceutical Manufacturing Companies Listed in Amman Stock Exchange; Journal of Social Sciences (COES\&RJJSS), Vol.5, No.3, pp: 277-290. 


\section{Introduction}

Information-driven economy, information technology advancements, innovation-based competitiveness, interpersonal and intra-organizational relationships, strategy-related orientation, customer-focused products and services, international competition, resourcesextended practices, as well as intangibles-valued investments or goodwill-grounded value creation were all regarded as antecedents of academic and organizational interest in intellectual capital (Harrison and Sulliva Sr, 2000; Guthrie, 2001; Bontis and Fitz-enz, 2002; Mouritsen, 2003; Seleim et al., 2004; Wang and Chang, 2005; Ng, 2006; Der Zahn et al., 2007; Oliveras et al., 2008; Rodriguez-Ruiz and Fernandez-Menendez, 2009; Kianto et al., 2010; Taliyang and Jusop, 2011; Neysi, et al., 2012 and Moghadam et al., 2013; Cricelli et al., 2014 and Altuner et al., 2015).

Chen (2009) attributed the importance of intellectual capital to underestimation or overestimation of organization's value. That is, there is a gap between book value and market value. According to him, for organizations to determine the real value, organizations have to evaluate their intangible assets. These assets cover three major elements, human capital, organizational (structural) capital, and relational capital (Kamukama, 2013; Murthy and Mouritsen, 2011; Mouritsen, 2009). Sullivan (1999, as cited in Chahal and Bakshi, 2015) divided intellectual capital into two types; competencies-related capital and relationships-based capital. The first type refers to human and structural capital, and the second one signifies the relational capital. Ferenhof et al. (2015) added a fourth dimension which is the social capital. Chen (2009) defined human capital as employees' knowledge, skills, and experiences employed in organization's value creation process. Knowledge, skills, experiences, capabilities, competencies, learning, attitudes, education as well as creativity were all deemed as components of human capital. Bozbura (2004) added other components of the human capital, which are leadership, risk-taking in addition to problemsolving capabilities.

Seeing structural capital as a capability that can be used by an organization to stand up to its challenges, Chahal and Bakshi (2015) argued that structural capital consists of an organization's elements such as the organizational processes and information technology infrastructure. According to Hsu and Wang (2012), organizational processes concern the creation of knowledge resources, while information technology systems belong to the management of such resources. On the part of relational capital, Gannon et al. (2008) described this sub-dimension of intellectual capital as set of external relationships between an organization and its customers and other organizations. Han and Li (2015) measured the relational capital using relationship with customers, suppliers and partners.

Various outcomes of intellectual capital were reported in the literature. Business performance was one of the most variables studied in the context of intellectual capital. Many works revealed that business performance is positively related, either directly or indirectly, to intellectual capital. Wang and Chang (2005) examined business performance of information technology industry in Taiwan, and showed that business performance is positively related to intellectual capital. Sharabati et al. (2010) studied the relationship between intellectual capital and business performance in pharmaceutical industries in Jordan. Their results confirmed that intellectual capital has a positive impact on business performance. Zeghal and Maaloul (2010) investigated the influence of intellectual capital in high-tech, traditional, and service companies in UK on economic and financial performance. 
Their findings asserted the positive influence of intellectual capital on economic and financial performance.

Intellectual capital, on the other hand, was found to have a positive impact on organization's competitive advantage (Chahal and Bakshi, 2015). Altuner et al. (2015) pointed out a significant relationship among intellectual capital, corporate governance, and corporate social responsibility. For Ling (2012), intellectual capital is positively correlated to an organization's global marketing and global entrepreneurship initiatives. Moghadam et al. (2013) concluded a positive relationship between human and structural capital and organizational capital. Massingham and Tam (2015) studied the relationship between three constructs, human capital, work activity, and employee pay. They conceptualized human capital in terms of employee capability, employee satisfaction, and employee commitment. Their findings confirmed a positive relationship between human capital (employee capability and employee satisfaction) and work activity significance. Additionally, the results showed that employee capability is positively related to employee pay.

Market value, on the other hand, was defined operationally by Tseng et al. (2015, p.160) as "Share price of a closing quotation of common stock at the end of the period". A recent study conducted by Nimtrakoon (2015) to examine the relationship between intellectual capital, firm's market value and financial performance of technology firms in Indonesia, Malaysia, Philippines, Singapore, and Thailand, revealed a positive impact of intellectual capital on market value and financial performance. Studying measurement and application of intellectual capital in Turkey, Bozbura (2004) pointed out positive and strong relationships between organizations' human and relational capital and market value as well as book value. According to Anam et al. (2011), the positive impact of intellectual capital disclosure on market value was well established and documented in some previous studies. Despite the results of prior researches that confirmed the relationship between intellectual capital and market value, little studies have been conducted to examine the same relationship in Jordanian pharmaceutical manufacturing companies listed in Amman Stock Exchange. Hence, the aim of this study is to explore the impact of intellectual capital disclosure by Jordanian pharmaceutical manufacturing listed companies on their market value.

\section{Literature review and hypotheses development}

The disclosure of intellectual capital has been regarded as a problematic issue due to the fact that companies prefer not to report their intangibles in consequence of the role that intangibles have in company's competitive advantage (Holland, 2003). However, companies recognize the importance of intellectual capital and tend to invest in intellectual capital in order to improve their competitive advantage and success (Nimtrakoon, 2015). Investigating intellectual capital and market value for US electronic companies, and conceptualizing human capital, customer capital, innovation capital, and process capital as sub-dimensions of intellectual capital, Wang (2008) pointed out a positive relationship between intellectual capital and market value. The aim of Liu et al.'s (2009) research was to investigate the impact of intellectual capital information in information technology listed companies in the Taiwan Stock Exchange on corporate value and value creation. Their results asserted a positive relationship between these variables.

Zeghal and Maaloul (2010) examined the association between intellectual capital and three types of performance; economic, financial and stock market of UK companies. Their findings showed a significant relationship between intellectual capital and stock market value, and restricted on high tech companies. The significant positive impact of intellectual 
capital disclosure on market capitalization was also reported by prior studies (Anam et al., 2011 and Abdolmohammadi, 2005).

Tan et al. (2007) investigated the relationship between intellectual capital and financial returns of 150 listed companies on the Singapore Exchange. The selected financial returns were return on equity, earning per share, and annual share returns. The results supported the hypothesis that both intellectual capital and financial return have a significant relationship. In their study on Taiwan's listed companies, Chen et al. (2005) examined the relationship between intellectual capital, market value and financial performance. Their results highlighted the significance of intellectual capital in improving profitability and return growth.

On their research on manufacturing companies in Thailand, Phusavat et al. (2011) reported a positive relationship between intellectual capital and companies' performance, especially, return on equity, revenue growth, and employee productivity. In her recent research paper, Nimtrakoon (2015) examined the impact of intellectual capital on market value and financial performance. The results of the research accepted the hypothesis that intellectual capital is significantly related to market value and margin ration as well as return on assets. Orens et al. (2009) regarded market value as function of various factors, such as the disclosure of intellectual capital and company's profitability. That is, a company can enhance its value by reporting more about its intellectual capital components. Their results, also, indicated a positive association between company's market value and its profitability. As for trading volume, the findings pointed out a positive association between trading volume and intellectual capital disclosure. In order to explore the impact of intellectual capital disclosure in the annual reports by Jordanian pharmaceutical manufacturing listed companies on their market value in the presence of return on assets and trading value as control variables, the following hypotheses were drawn:

H1:Disclosure of intellectual capital components by Jordanian pharmaceutical manufacturing listed companies is positively related to market value.

H2:Disclosure of intellectual capital components by Jordanian pharmaceutical manufacturing listed companies and return on assets are positively related to market value.

H3: Disclosure of intellectual capital components by Jordanian pharmaceutical manufacturing listed companies and trading value are positively related to market value.

H4: Disclosure of intellectual capital components by Jordanian pharmaceutical manufacturing listed companies, return on assets and trading value are positively related to market value.

\section{Research methodology}

3.1Population, sample and data collection

The population of the research comprises all Jordanian pharmaceutical manufacturing companies listed in the Amman Stock Exchange before until 2012. There were 6 publicly listed companies prior to 2012, Dar Al-dawa, the Arab Center for Pharmaceutical and Chemical Industries, the Jordanian Pharmaceutical Manufacturing Company, Middle East Pharmaceutical and Chemical Industries Company, Hayat Pharmaceutical Industries Company, and Philadelphia Pharmaceutical Company. Research sample involves all these companies. In order to collect data, journal papers, books, magazines, in addition to the financial statements and annual reports of Jordanian pharmaceutical companies were used as secondary and primary sources to 
collect data. Financial statements and annual reports were used by various studies to collect data about intellectual capital disclosure (De Silva et al., 2013).

3.2Research conceptual model

The research is intended to examine relationships between three major variables. Intellectual capital disclosure is the independent variable. It comprises three dimensions; human capital, structural capital, and relational capital. Company's market value is the dependent variable, whilst company's profitability (return on assets) and annual trading value were the control variables in the relationship between independent and dependent variables. Particularly, the latter two variables were utilized as independent variables for the sake of testing the research hypotheses. Figure 1 pictures the conceptual model of the research.

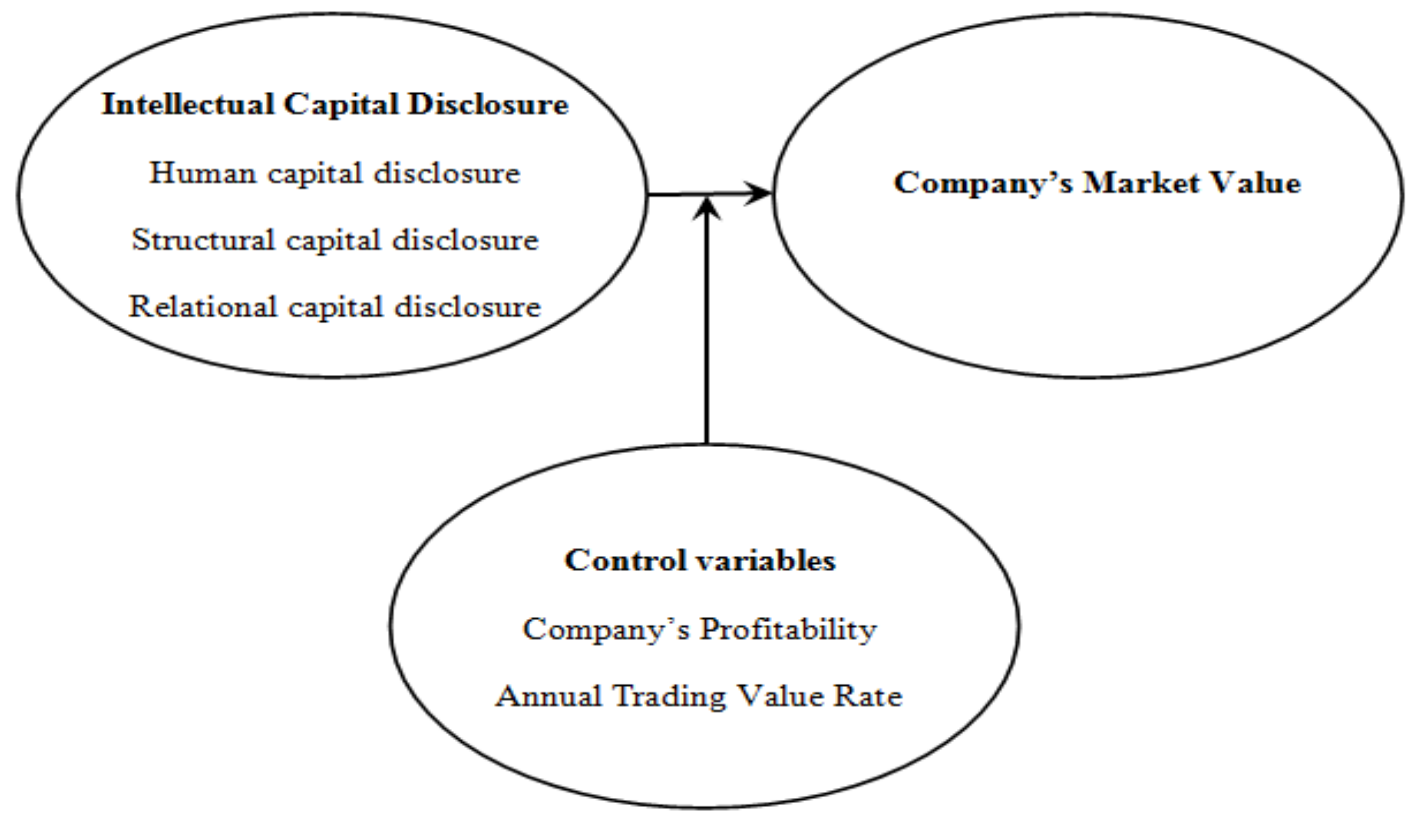

3.3Measurements

Figure 1. Research Conceptual Model

Drawing from the literature review, numerous disclosure-related items were identified for each dimension of intellectual capital, i.e., human capital, structural capital and relational capital, in order to determine the extent of disclosed intellectual capital. According to Khalique et al. (2015, p.226), human capital can be measured using competencies, attitudes, and intellectual agility such as education, skills, experiences, motivation, innovation, and flexibility, while structural capital is grounded on knowledge embodied in procedures, systems, networks, and databases. Goebel (2015) carried out a content analysis of intellectual capital disclosure. Her results highlighted that the major sub-dimensions of relational capital used in previous studies were company reputation, brands, customers, distribution channels, licensing agreements, and business collaborations. For the current research to measure the extent of intellectual capital disclosure, the items of intellectual capital disclosure were selected based on prior studies (Beattie \& Thomson, 2007; Nielsen \& Madsen, 2009; Indra, 2011; Jing Li et al., 2012; and; Claver-Cortés et al., 2015). These items can be seen in Table 1. A value of (1) was used to indicate "disclosure" while (0) denotes "non-disclosure". The sum of all disclosure values in annual reports divided by the grand total of all disclosures for each company in a particular year results in intellectual capital disclosure percentage. Market value along with profitability and trading value were measured using data available on Amman Stock Exchange website. 
Table 1. Items of intellectual capital (IC) disclosure

\begin{tabular}{ll}
\hline IC dimensions & Disclosure items \\
\hline Human capital & $\begin{array}{l}\text { Employee's age, education, skills, training programs, experience, } \\
\text { productivity, utilities, health and safety plus employee's social } \\
\text { participation. }\end{array}$ \\
\hline Structural capital & $\begin{array}{l}\text { Patents, trademarks, organizational structure, information systems, } \\
\text { information technology infrastructure and internal networks, } \\
\\
\text { managerial style, besides research and development. }\end{array}$ \\
\hline Relational capital & $\begin{array}{l}\text { Relationships with customers, suppliers, investors as well as } \\
\text { community, together with advantages, distribution channels, and } \\
\\
\text { market share. }\end{array}$ \\
\hline
\end{tabular}

\section{Data analysis and results}

4.1Research measurement models

Four models were employed to measure relationship between disclosure of intellectual capital components, return on assets, and trading value. The first model is dedicated to test the relationship between intellectual capital disclosure and market value, as can be seen in equation 1. The second model, depicted by equation.2, aimed at testing the relationship between intellectual capital disclosure, return on assets and market value. The third one supposed to measure the relationship between intellectual capital disclosure, trading value and market value (see equation 3). Finally, model 4 measures the relationship between intellectual capital disclosure, return on assets, trading value and market value, as shown in equation 4.

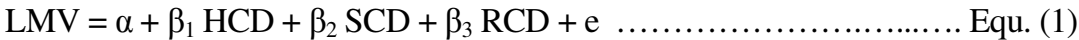

$$
\begin{aligned}
& \mathrm{LMV}=\alpha+\beta 1 \mathrm{HCD}+\beta 2 \mathrm{SCD}+\beta 3 \mathrm{RCD}+\beta 4 \mathrm{ROA}+\mathrm{e} \ldots \ldots \ldots \ldots \ldots . . . . . \text { Equ. (2) } \\
& \mathrm{LMV}=\alpha+\beta 1 \mathrm{HCD}+\beta 2 \mathrm{SCD}+\beta 3 \mathrm{RCD}+\beta 4 \mathrm{LTV}+\mathrm{e} \ldots \ldots \ldots \ldots \ldots . . . . . . \mathrm{Equ} . \text { (3) } \\
& \mathrm{LMV}=\alpha+\beta 1 \mathrm{HCD}+\beta 2 \mathrm{SCD}+\beta 3 \mathrm{RCD}+\beta 4 \mathrm{ROA}+\beta 5 \mathrm{LTV}+\mathrm{e} \ldots . \text { Equ. (4) }
\end{aligned}
$$

Where:

LMV: the natural logarithm of the market value

HCD: human capital disclosure

SCD: structural capital disclosure

RCD: relational capital disclosure

e: standard error

ROA: return on assets.

LTV: the natural logarithm of trading value

4.2Normality test

Kolmogorov-Smirnov \& Shapiro-Wilk tests were used to test sample for normality. Table 2 summarizes the results of this test. According to the results in Table 2, all variables are normally distributed (Sig.>0.05).

Table 2. Normality test results

\begin{tabular}{lcccccc}
\hline & \multicolumn{3}{l}{ Kolmogorov-Smirnov (a) } & \multicolumn{3}{c}{ Shapiro-Wilk } \\
\hline Variable & Statistic & & & & & Sig. \\
\hline Market value & s & df & Sig. & Statistics & df & 0.850 \\
Annual rate of trading value & 0.119 & 34 & 0.200 & 0.976 & 34 & 0.858 \\
Return on assets & 0.125 & 34 & 0.200 & 0.982 & 34 & 0.85 \\
Human capital disclosure & 0.130 & 34 & 0.185 & 0.934 & 34 & 0.052 \\
Structural capital discloser & 0.135 & 34 & 0.120 & 0.952 & 34 & 0.250 \\
Relational capital disclosure & 0.141 & 34 & 0.083 & 0.947 & 34 & 0.160 \\
\hline
\end{tabular}

4.3Multicollinearity test 
Pearson correlation coefficients were used to test multicollinearity between the independent variables. This problem arises if independent variables are dependent on each other. Table 3 illustrates the correlations matrix of predictors. The table shows that the highest correlation was between structural capital and intellectual capital $(r=0.764)$. The other correlation values were equal or less than 0.682. Hence, independent variables have no multicollinearity problem.

Table 3. Correlation Matrix

\begin{tabular}{ccccccc}
\hline Variable & ROA & TV & HC & SC & RC & IC \\
\hline ROA & 1 & & & & & \\
TV & 0.427 & 1 & & & & \\
HC & 0.486 & 0.487 & 1 & & & \\
SC & 0.086 & 0.262 & 0.316 & 1 & 1 & \\
RC & 0.241 & 0.059 & 0.116 & 0.293 & 0.664 & 1 \\
IC & 0.386 & 0.082 & 0.682 & 0.764 & \\
\hline
\end{tabular}

4.4Autocorrelation test

The Durbin-Watson test was used to identify the presence of correlations of residuals in regression model. The test depends on the comparison between DV tabulated (dL and $\mathrm{dU})$ and calculated values. No autocorrelation problem found if DW calculated is greater than dU (Montgomery et al., 2001). The results of this test are shown in Table 4. Table 4 shows that all DW calculated for all hypotheses were greater than the value of $\mathrm{dU}$ (the upper critical value), which means that the regression model is free of autocorrelation problem.

Table 4. Results of Durbin-Watson Test

\begin{tabular}{ccccc}
\hline H & DW statistic & dL & dU & Result \\
\hline H01 & 1.723 & 1.295 & 1.654 & no autocorrelation \\
H02 & 1.781 & 1.236 & 1.724 & no autocorrelation \\
H03 & 1.902 & 1.236 & 1.724 & no autocorrelation \\
H04 & 1.8201 & 1.175 & 1.799 & no autocorrelation \\
\hline
\end{tabular}

4.5Heteroscedasticity Test

Breusch-Pagan-Godfrey test was used to test heteroscedasticity in the regression model. Williams (2015, p.4) stated that it tests the null hypothesis that the error variance are equal versus the alternative hypothesis that the error variances are a multiplicative function of one or more variables. The aim of this test is to identify the variables that cause heteroscedasticity. Table 5 presents the results of heteroscedasticity test; it indicates that the error variance is a linear function of one or more variables (sig.>0.05).

Table 5. Results of Heteroscedasticity Test

\begin{tabular}{cccc}
\hline H0 & F statistic & Sig. & Result \\
\hline H01 & 0.9741 & 0.3298 & $\begin{array}{c}\text { constant error } \\
\text { variance } \\
\text { constant error } \\
\text { variance } \\
\text { constant error } \\
\text { variance } \\
\text { constant error } \\
\text { variance }\end{array}$ \\
\hline H04 & 0.1076 & 0.7470 & 0.790 \\
\hline
\end{tabular}

4.6Descriptive statistics of intellectual capital disclosure components

Extent of intellectual capital disclosure. Table 6 illustrates status of companies according to their extent of intellectual capital disclosure. The mean of intellectual capital disclosure for the Jordanian pharmaceutical manufacturing companies was (46.63\%, $\mathrm{SD}=19.32$ ). The mean of

Table 6. Companies extent of intellectual capital disclosure (2007-2012) 


\begin{tabular}{ccccccccc}
\hline Var. & DD & ACPCI & MEPCI & JPMC & HPIC & PPC & Mean & SD \\
\hline HC & $22.00 \%$ & $48.00 \%$ & $42.50 \%$ & $14.67 \%$ & $42.33 \%$ & $66.83 \%$ & $39.39 \%$ & 27.67 \\
SC & $79.67 \%$ & $47.00 \%$ & $58.33 \%$ & $25.33 \%$ & $25.17 \%$ & $48.17 \%$ & $47.28 \%$ & 27.57 \\
RC & $47.67 \%$ & $40.67 \%$ & $81.00 \%$ & $68.83 \%$ & $33.50 \%$ & $47.67 \%$ & $53.22 \%$ & 27.19 \\
IC & $49.78 \%$ & $45.22 \%$ & $60.61 \%$ & $36.28 \%$ & $33.67 \%$ & $54.22 \%$ & $46.63 \%$ & 19.32 \\
\hline
\end{tabular}

HC: human capital; SC: structural capital; RC: relational capital; IC: intellectual capital; DD: Dar Al-dawa; ACPCI: the Arab Center for Pharmaceutical and Chemical Industries; MEPCI: Middle East Pharmaceutical and Chemical Industries Company; JPMC: the Jordanian Pharmaceutical Manufacturing Company; HPIC: Hayat Pharmaceutical Industries Company; PPC: Philadelphia Pharmaceutical Company.

RC disclosure for all companies was 53.22.39\% ( $\mathrm{SD}=27.19)$. SC and $\mathrm{HC}$ reported mean values of $(47.28,39.39, \mathrm{SD}=27.57,27.67)$ respectively. Furthermore, the table clarifies that the Middle East pharmaceutical and chemical industries company ranked first in intellectual capital disclosure $(\mathrm{M}=60.6 \%)$, whilst, Hayat Pharmaceutical Industries Company was the last one $(\mathrm{M}=33.6 \%)$. As for $\mathrm{HC}$, the mean of $\mathrm{HC}$ disclosure for all companies was 39.39\%. Philadelphia Pharmaceutical Company was the first in HC disclosure $(\mathrm{M}=66.83 \%)$ versus the Jordanian Pharmaceutical Manufacturing Company $(\mathrm{M}=14.67 \%)$. With respect to $\mathrm{SC}$, the results indicate that the mean of all companies was 47.28\%. Dar Al-dawa with the first rank $(\mathrm{M}=79.67 \%)$ and Hayat Pharmaceutical Industries Company in the last rank $(\mathrm{M}=25.17 \%)$. As regards $\mathrm{RC}$, the mean of all companies was $(53.22 \%)$. The Middle East pharmaceutical and chemical industries company ranked first in intellectual capital disclosure $(\mathrm{M}=81.00 \%)$ whereas Hayat Pharmaceutical Industries Company in the last rank $(\mathrm{M}=33.50 \%)$.

4.7Descriptive statistics of financial indicators

As can depicted in Table 7, the mean value of ROA for the Jordanian pharmaceutical companies (2007-2012) equals 0.862 ( $\mathrm{SD}=6.571)$. Hayat pharmaceutical industries company has the highest rate of $\mathrm{ROA}(\mathrm{M}=6.052, \mathrm{SD}=3.607)$. The lowest rate of $\mathrm{ROA}$ was for the Arab center for pharmaceutical and chemical industries $(\mathrm{M}=-3.501, \mathrm{SD}=6.489)$. The mean of TV for all companies (2007-2012) was 3.233 million JDs. Dar Al-dawa has the highest TV $(\mathrm{M}=14.811, \mathrm{SD}=21.802)$ compared to Philadelphia Pharmaceutical Company $(\mathrm{M}=0.376$, $\mathrm{SD}=0.665$ ). The mean value of MV for all companies (2007-2012) was 27.046 million JDs with SD equal to 24.471 million JDs. Dar Al-dawa rank first in terms of MV (M=70.508, $\mathrm{SD}=15.880)$ while Philadelphia pharmaceutical company stands last $(\mathrm{M}=2.132, \mathrm{SD}=0.492)$.

Table 7. Distribution of pharmaceutical companies by virtue of financial indicators (2007-2012)

\begin{tabular}{|c|c|c|c|c|c|c|c|c|}
\hline $\begin{array}{c}\text { Indicat } \\
\text { or }\end{array}$ & $\begin{array}{c}\text { Measu } \\
\text { re }\end{array}$ & DD & $\begin{array}{c}\text { ACPC } \\
\text { I }\end{array}$ & $\begin{array}{c}\text { MEP } \\
\text { CI }\end{array}$ & JPMC & HPIC & PPC & Total \\
\hline \multirow{2}{*}{ ROA } & M & 2.815 & -3.501 & -2.075 & 4.148 & 6.052 & -1.722 & 0.862 \\
\hline & SD & 6.523 & 6.489 & 7.748 & 0.978 & 3.607 & 6.797 & 6.571 \\
\hline \multirow{2}{*}{ TV } & M & 14.811 & 0.483 & 1.292 & 1.700 & 0.732 & 0.376 & 3.233 \\
\hline & SD & 21.802 & 0.454 & 1.015 & 1.086 & 0.730 & 0.665 & 9.808 \\
\hline \multirow[t]{2}{*}{ MV } & M & 70.508 & 10.983 & 38.907 & 28.433 & 11.310 & 2.132 & $\begin{array}{c}27.04 \\
6\end{array}$ \\
\hline & SD & 15.880 & 21.807 & 14.570 & 3.280 & 2.299 & 0.492 & $\begin{array}{c}24.47 \\
1\end{array}$ \\
\hline \multirow{3}{*}{\multicolumn{4}{|c|}{$\begin{array}{l}\text { ROA: return on assets; TV: trading val } \\
\text { deviation; } \quad \text { DD: }\end{array}$}} & ue; MV & orlot & & . $S$ & tandard \\
\hline & & & & & & ACPCI: & \multicolumn{2}{|c|}{ the Arab } \\
\hline & & & & Indu & & MEPCI: & Middl & East \\
\hline Pharmac & atical & id Che & nical In & lustries & Compa & ; $\quad$ JPMC & 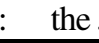 & rdanian \\
\hline
\end{tabular}


Pharmaceutical Manufacturing Company; HPIC: Hayat Pharmaceutical Industries Company; PPC: Philadelphia Pharmaceutical Company.

\subsection{Hypotheses testing}

Multiple linear regression was used to test research hypotheses. Hypothesis 1 assumed that the disclosure of intellectual capital components by Jordanian pharmaceutical manufacturing companies is positively related to market value (MV). The findings illustrated in Table 8 revealed a significant impact of the disclosure of intellectual capital components on MV ( $\mathrm{r}=0.712, \mathrm{~F}=10.944$, sig.=0.000). The value of $\mathrm{R}$ squared indicated that $50.6 \%$ of the variance in the MV can be explained by the disclosure of intellectual capital components.

Table 8. Results of intellectual capital components disclosure on market value

\begin{tabular}{|c|c|c|c|c|c|c|c|c|c|}
\hline \multirow{2}{*}{ DV } & \multirow{2}{*}{$\mathbf{R}$} & \multirow{2}{*}{$\mathbf{R}^{2}$} & \multirow{2}{*}{$\mathbf{F}$} & \multirow{2}{*}{ Sig. } & \multicolumn{5}{|c|}{ Regression Coefficients } \\
\hline & & & & & & $\beta$ & $\mathrm{SE}$ & $\mathbf{t}$ & Sig. \\
\hline MV & 0.712 & 0.506 & $\begin{array}{c}10.94 \\
4\end{array}$ & 0.000 & $\begin{array}{l}\mathrm{HC} \\
\mathrm{SC} \\
\mathrm{RC}\end{array}$ & $\begin{array}{l}2.512 \\
1.973 \\
1.147\end{array}$ & $\begin{array}{l}0.551 \\
0.574 \\
0.556\end{array}$ & $\begin{array}{l}4.559 \\
3.435 \\
2.061\end{array}$ & $\begin{array}{l}0.000 \\
0.002 \\
0.047\end{array}$ \\
\hline
\end{tabular}

Table 8 shows that the significant impact of each component of IC, $\mathrm{HC}(\beta=2.512, \mathrm{t}=4.559$, sig.=0.000), $\mathrm{SC} \quad(\beta=1.973, \mathrm{t}=3.435$, sig.=0.002), $\mathrm{RC} \quad(\beta=1.147, \mathrm{t}=2.061, \mathrm{sig} .=0.047)$. Accordingly, there is a positive significant impact of the disclosure of intellectual capital components by Jordanian pharmaceutical manufacturing companies on their market value. Hence, the following regression model was formulated:

$\mathrm{LMV}=16.043+2.512 \mathrm{HCD}+1.973 \mathrm{SCD}+1.147 \mathrm{RCD}+\mathrm{e}$

Stepwise regression analysis was conducted to detect the more significant impact of these components. The results of stepwise regression presented in Table 9 pointed out that HC disclosure explained $17.5 \%$ of the variance in the market value of pharmaceutical companies. Explanation percentage was increased to $44.1 \%$ right after SC was entered into the model, and increased also to 50.6 when $\mathrm{RC}$ added finally into the model.

Table 9. Stepwise results of intellectual capital components disclosure on market value

\begin{tabular}{cccccccccc}
\hline $\begin{array}{c}\text { Mode } \\
\mathbf{l}\end{array}$ & $\mathbf{M V}$ & $\boldsymbol{\beta}$ & $\mathbf{t}$ & Sig. & $\mathbf{R}$ & $\mathbf{R}^{2}$ & $\mathbf{S E}$ & $\mathbf{F}$ & Sig. \\
\hline $\mathbf{1}$ & $\mathbf{H C}$ & 1.760 & 2.685 & 0.011 & 0.418 & 0.175 & 1.073 & 7.209 & 0.011 \\
\hline \multirow{2}{*}{$\mathbf{2}$} & $\mathbf{H C}$ & 2.483 & 4.301 & 0.000 & & & & 13.01 & 0.000 \\
& $\mathbf{S C}$ & 2.295 & 3.962 & 0.000 & 0.664 & 0.441 & 0.897 & 0 & \\
\hline & HC & 2.512 & 4.559 & 0.000 & & & & & \\
$\mathbf{3}$ & SC & 1.973 & 3.435 & 0.002 & & & & 10.94 & 0.000 \\
& RC & 1.147 & 2.061 & 0.047 & 0.712 & 0.506 & 0.856 & 4 & 0.00
\end{tabular}

Hypothesis 2 presumed that the disclosure of intellectual capital components by Jordanian pharmaceutical manufacturing companies and return on assets (ROA) is positively related to market value (MV). The results shown in Table 10 revealed a significant impact of the disclosure of intellectual capital components and ROA on MV ( $\mathrm{r}=0.713, \mathrm{~F}=7.754$, sig. $=0.000$ ). The value of $\mathrm{R}$ squared indicated that $50.8 \%$ of the variance in the market value can be explained by the disclosure of intellectual capital components and ROA.

Table 10. Results of intellectual capital components disclosure on market value 


\begin{tabular}{|c|c|c|c|c|c|c|c|c|c|}
\hline \multirow{2}{*}{ DV } & \multirow{2}{*}{$\mathbf{R}$} & \multirow{2}{*}{$\mathbf{R}^{2}$} & \multirow{2}{*}{$\mathbf{F}$} & \multirow{2}{*}{ Sig. } & \multicolumn{5}{|c|}{ Regression Coefficients } \\
\hline & & & & & & $\beta$ & SE & $\mathbf{t}$ & Sig. \\
\hline \multirow{4}{*}{ MV } & \multirow{4}{*}{0.713} & \multirow{4}{*}{0.508} & \multirow{4}{*}{7.754} & \multirow{4}{*}{0.000} & $\mathrm{HC}$ & 2.655 & 0.661 & 4.016 & 0.000 \\
\hline & & & & & $\mathrm{SC}$ & 2.026 & 0.604 & 3.353 & 0.002 \\
\hline & & & & & $\mathrm{RC}$ & 1.070 & 0.556 & 2.061 & 0.047 \\
\hline & & & & & ROA & 0.013 & 0.027 & 0.494 & 0.625 \\
\hline
\end{tabular}

Table 10 shows that the significant impact of each component of IC, HC $(\beta=2.655$, $\mathrm{t}=4.016$, sig.=0.000), $\mathrm{SC}(\beta=2.026, \mathrm{t}=3.353$, sig. $=0.002), \mathrm{RC} \quad(\beta=1.147, \mathrm{t}=2.061$, sig. $=0.047)$. Consequently, there is a positive significant impact of the disclosure of intellectual capital components by Jordanian pharmaceutical manufacturing companies and ROA on their market value. Hence, the following regression model was drawn:

$\mathrm{LMV}=16.124+2.655 \mathrm{HCD}+2.026 \mathrm{SCD}+1.070 \mathrm{RCD}+0.013 \mathrm{ROA}+\mathrm{e}$

Hypothesis 3 suggested that the disclosure of intellectual capital components by Jordanian pharmaceutical manufacturing companies and trading value (TV) is positively related to market value (MV). Table 11 displays the results of multiple regression test conducted to investigate the relationship between these constructs.

Table 11. Results of intellectual capital components disclosure and TV on market value

\begin{tabular}{|c|c|c|c|c|c|c|c|c|c|}
\hline \multirow{2}{*}{ DV } & \multirow{2}{*}{$\mathbf{R}$} & \multirow{2}{*}{$\mathbf{R}^{2}$} & \multirow{2}{*}{$\mathbf{F}$} & \multirow{2}{*}{ Sig. } & \multicolumn{5}{|c|}{ Regression Coefficients } \\
\hline & & & & & & $\beta$ & SE & $\mathbf{t}$ & Sig. \\
\hline \multirow{4}{*}{ MV } & \multirow{4}{*}{0.721} & \multirow{4}{*}{0.519} & \multirow{4}{*}{7.835} & \multirow{4}{*}{0.000} & $\mathrm{HC}$ & 1.710 & 0.651 & 2.626 & 0.014 \\
\hline & & & & & $\mathrm{SC}$ & 1.359 & 0.605 & 2.247 & 0.032 \\
\hline & & & & & $\mathrm{RC}$ & 0.844 & 0.513 & 1.644 & 0.111 \\
\hline & & & & & TV & 0.156 & 0.111 & 1.410 & 0.169 \\
\hline
\end{tabular}

Table 11 demonstrates a significant impact of intellectual capital components disclosure and TV on MV ( $\mathrm{r}=0.721, \mathrm{~F}=7.835$, sig. $=0.000)$. The value of $\mathrm{R}$ squared indicated that $51.9 \%$ of the variance in the market value can be explained by the disclosure of intellectual capital components and TV. The regression coefficients confirmed the significant impact of $\mathrm{HC}(\beta=1.710, \mathrm{t}=2.626$, sig. $=0.014)$ and $\mathrm{SC}(\beta=1.359, \mathrm{t}=2.247$, sig. $=0.032)$. Contrarily, $\mathrm{RC}$ $(\beta=0.844, \mathrm{t}=1.644$, sig. $=0.111)$ and TV $(\beta=0.156, \mathrm{t}=1.410$, sig. $=0.169)$ have no significant impact on the MV. Therefore, hypothesis 3 was no supported, and the following model was suggested:

$\mathrm{LMV}=14.144+1.710 \mathrm{HCD}+1.359 \mathrm{SCD}+0.844 \mathrm{RCD}+0.156 \mathrm{LTV}+\mathrm{e}$

Hypothesis 4 assumed that the disclosure of intellectual capital components by Jordanian pharmaceutical manufacturing companies, ROA and TV is positively related to MV. The results of multiple regression analysis are illustrated in Table 12. It was asserted that the disclosure of intellectual capital components by Jordanian pharmaceutical manufacturing companies, ROA and TV have a significant positive impact $(\mathrm{r}=0.721, \mathrm{~F}=5.851$, sig. $=0.001)$ on the MV. The value of R squared indicated that $52.0 \%$ of the variance in the market value can be explained by the disclosure of intellectual capital components, ROA and TV. The regression coefficients highlighted the significant impact of $\mathrm{HC}(\beta=1.744, \mathrm{t}=2.407$, sig. $=0.023)$ and $\mathrm{SC}(\beta=1.381, \mathrm{t}=2.193$, sig. $=0.037)$. On the other hand, $\mathrm{RC}(\beta=0.800, \mathrm{t}=1.465$, sig. $=0.155)$, ROA $(\beta=0.007, \mathrm{t}=0.283$, sig. $=0.779)$ and TV $(\beta=0.166, \mathrm{t}=1.406$, sig. $=0.171)$ have no significant impact on the MV. Therefore, hypothesis 4 was rejected, and the following model was offered:

$\mathrm{LMV}=14.040+1.744 \mathrm{HCD}+1.381 \mathrm{SCD}+0.800 \mathrm{RCD}+0.007 \mathrm{ROA}+0.166 \mathrm{LTV}+\mathrm{e}$ 
The Impact of Intellectual Capital Disclosure on Market Value:

Table 12. Results of intellectual capital components disclosure, ROA and TV on market value

\begin{tabular}{|c|c|c|c|c|c|c|c|c|c|}
\hline \multirow{2}{*}{ DV } & \multirow{2}{*}{$\mathbf{R}$} & \multirow{2}{*}{$\mathbf{R}^{2}$} & \multirow{2}{*}{$\mathbf{F}$} & \multirow{2}{*}{ Sig. } & \multicolumn{5}{|c|}{ Regression Coefficients } \\
\hline & & & & & & $\beta$ & SE & $\mathbf{t}$ & Sig. \\
\hline \multirow{5}{*}{ MV } & \multirow{5}{*}{0.721} & \multirow{5}{*}{0.520} & \multirow{5}{*}{5.851} & \multirow{5}{*}{0.001} & $\mathrm{HC}$ & 1.744 & 0.725 & 2.407 & 0.023 \\
\hline & & & & & SC & 1.381 & 0.630 & 2.193 & 0.037 \\
\hline & & & & & $\mathrm{RC}$ & 0.800 & 0.546 & 1.465 & 0.155 \\
\hline & & & & & ROA & 0.007 & 0.026 & 0.283 & 0.779 \\
\hline & & & & & $\mathrm{TV}$ & 0.166 & 0.118 & 1.406 & 0.171 \\
\hline
\end{tabular}

\section{Discussion and conclusion}

The aim of this study was to examine the impact of intellectual capital disclosure by the Jordanian pharmaceutical manufacturing public-listed companies in Amman Stock Exchange on their market value in the presence of return on assets and trading value as control variables. The results supported the hypothesis that intellectual capital disclosure (human capital, structural capital, and relational capital) have a statistically significant impact on companies' market value. Intellectual capital components explained 50.6\% of the variance in the market value. $\mathrm{HC}, \mathrm{SC}$ and $\mathrm{RC}$ explained $17.5 \%, 12.7 \%$ and $11.3 \%$ respectively of the variance in the market value. Similar results were echoed in prior studies in numerous countries such as Nimtrakoon (2015) who examined the relationship between intellectual capital, firm's market value and financial performance of technology firms in Indonesia, Malaysia, Philippines, Singapore, and Thailand, Bozbura (2004) who found strong relationships between organizations' $\mathrm{HC}$ and $\mathrm{RC}$ and market value as well as book value in Turkey, and Anam et al. (2011) who pointed out a positive impact of intellectual capital disclosure on market value. in fact, the findings of this research is consistent of several previous studies (Chen et al., 2005; Tan et al., 2007; Wang, 2008; Liu et al., 2009; Orens et al., 2009 and Phusavat et al., 2011). Moreover, it was found that both intellectual capital disclosure and ROA have an impact on the market value. However, the explanation percentage wasn't affected too much (50.6\%-50.8\%) in the presence of ROA due to the insignificant impact of ROA. The same thing is right for the insignificant impact of TV on market value. In light of these findings, it was concluded that the evaluation of firm's market value using the extent of intellectual capital disclosure is more important than using financial indicators, due to the changing nature of such indicators compared with intellectual capital components.

\section{Practical implications and recommendations}

For organizations to make good decisions, information on intellectual capital components should be disclosed, either on quantitative or qualitative information. Furthermore, the Jordanian pharmaceutical manufacturing companies have to extend their intangible investments in accordance with its role in enhancing the firm's market value, through itemizing a specific account for the investment in intellectual capital, which periodically assessed. Concerning the disclosure of intellectual capital components, the Jordanian pharmaceutical manufacturing companies should pay more attention to the extent of information disclose motivated by the significant influence of such disclosure on stakeholders evaluations of future returns. The disclosure can be done by specified annual bulletins attached with the financial reports. Finally, further studies is recommended to assess the extent and impact of intellectual capital disclosure using other constructs such as profit dividends and future economic expectations in other sectors. 


\section{References}

-Abdolmohammadi, M. (2005). Intellectual capital disclosure and market capitalization. Journal of Intellectual Capital, 6 (3), 397-416.

-Altuner, D., Çelik, S. \& Güleç, T. (2015). The linkages among intellectual capital, corporate governance and corporate social responsibility. Corporate Governance, 15 (4), 491-507.

-Anam, O., Fatima, A. \& Majdi, A. (2011). Effects of intellectual capital information disclosed in annual reports on market capitalization Evidence from Bursa Malaysia. Journal of Human Resource Costing \& Accounting, 15 (2), 85-101.

-Beattie, Vivien \& Thomson, Sarah Jane (2007). Lifting the lid on the use of content analysis to investigate intellectual capital disclosures. Accounting Forum, 31 (2007), 129163.

-Bontis, N. \& Fitz-enz, J. (2002). Intellectual capital ROI: a casual map of human capital antecedents and consequences. Journal of Intellectual Capital, 3 (3), 223-247.

-Bozbura, F. (2004). Measurement and application of intellectual capital in Turkey. The Learning Organization, 11 (4/5), 357-367.

-Chahal, H. \& Bakshi, P. (2015). Examining intellectual capital and competitive advantage relationship: role of innovation and organizational learning. International Journal of Bank Marketing, 33 (3), 376-399.

-Chen, M., Cheng, S. \& Hwang, Y. (2005). An empirical investigation of the relationship between intellectual capital and firms' market value and financial performance. Journal of Intellectual Capital, 6 (2), 159-176.

-Chen, Sh. (2009). Identifying and prioritizing critical intellectual capital for e-learning companies. European Business Review, 21 (5), 438-452.

-Claver-Cortés, E., Zaragoza-Sáez, P., Molina-Manchón, H. \& Úbeda-García, M. (2015). Intellectual capital in family firms: human capital identification and measurement. Journal of Intellectual Capital, 16 (1), 199-223.

-Cricelli, L., Greco, M. \& Grimaldi, M. (2014). An overall index of intellectual capital. Management Research Review, 37 (10), 880-901.

-De Silva, T., Stratford, M. \& Clark, M. (2013). Intellectual capital reporting: a longitudinal study of New Zealand companies. Journal of Intellectual Capital, 15 (1), 157-172.

-Der Zahn, JL., Singh, I. \& Heniro, J. (2007). Is there an association between intellectual capital disclosure, underpricing and long-run performance? Journal of Human Resource Costing \& Accounting, 11 (3), 178-213.

-Ferenhof, H., Durst, S., Bialecki, M. \& Selig, P. (2015). Intellectual capital dimensions: state of the art in 2014. Journal of Intellectual Capital, 16 (1), 58-100.

-Gannon, C., Lynch, P., \& Harrington, D. (2008). Managing intellectual capital for sustained competitive advantage in the Irish tourism industry. Waterford Institute of Technology (WIT). Tourism and hospitality Research in Ireland Conference (THRIC), 1617 June, DIT.

-Goebel, V. (2015). Is the literature on content analysis of intellectual capital reporting heading towards a dead end? Journal of Intellectual Capital, 16 (3), 681-699.

-Guthrie, J. (2001). Measurement and reporting of intellectual capital. Journal of Intellectual Capital, 2(1), p. 27-41.

-Han, Y. \& Li, D. (2015). Effects of intellectual capital on innovative performance: The role of knowledge-based dynamic capability. Management Decision, 53 (1), 40-56.

-Harrison, S. \& Sulliva Sr, P. (2000). Profiting from intellectual capital: Learning from leading companies. Journal of Intellectual Capital, 1(1), p. 33-46. 
-Holland, J. (2003). Intellectual capital and the capital market - organization and competence. Accounting, Auditing \& Accountability Journal, 16 (1), 39-48.

-Hsu, L.C. and Wang, C.H. (2012). Clarifying the effect of intellectual capital on performance: the mediating role of dynamic capability, British Journal of Management, Vol. 23 No. 2, pp. 179-205.

-Indra, Abeysekera. (2011). Civil War, Stock Return, and Intellectual Capital Disclosure in Sri Lanka. Advances in Accounting, incorporating Advances in International Accounting, 27 (2011), PP. 331-337

-Jing Li, Musa Mangena, Richard Pike. (2012). The effect of audit Committee characteristics on intellectual capital disclosure. The British Accounting Review, 44 (2012), pp. $98-110$

-Kamukama, N. (2013). Intellectual capital: company's invisible source of competitive advantage. Competitiveness Review: An International Business Journal, 23 (3), 260-283.

-Khalique, M., Bontis, N., Shaari, J. \& Isa, A. (2015). Intellectual capital in small and medium enterprises in Pakistan. Journal of Intellectual Capital, 16 (1), 224-238.

-Kianto, A., Hurmelinna-Laukkanen, P. \& Ritala, P. (2010). Intellectual capital in serviceand product-oriented companies. Journal of Intellectual Capital, 11 (3), 305-325.

-Ling, YH. (2012). The influence of intellectual capital on global initiatives. The journal of information and knowledge management systems, 42 (1), 129-144.

-Liu, DY., Tseng, KA. \& Yen, SW. (2009). The incremental impact of intellectual capital on value creation. Journal of Intellectual Capital, 10 (2), 260-276.

-Massingham, P. \& Tam, L. (2015). The relationship between human capital, value creation and employee reward. Journal of Intellectual Capital, 16 (2), 390-418.

-Moghadam, S. Khayat, Zabihi, M. R., Kargaran, M. \& Hakimzadeh, A. (2013). Intellectual capital and organizational learning capability. Journal of Soft Computing and Applications, 2013, 1-9.

-Montgomery, D. C., Peck, E. A. \& Vining, G. G. (2001). Introduction to linear regression analysis. ( $3^{\text {rd }}$ ed.). UNA, New York: John Wiley \& Sons.

-Mouritsen, J. (2003). Overview: intellectual capital and the capital market- the circulability of intellectual capital. Accounting, Auditing \& Accountability Journal, 16 (1), 18-30.

-Mouritsen, J. (2009). Classification, measurement and the ontology of intellectual capital entities. Journal of Human Resource Costing \& Accounting, 13 (2), 154-162.

-Murthy, V. \& Mouritsen, J. (2011). The performance of intellectual capital: Mobilising relationships between intellectual and financial capital in a bank. Accounting, Auditing \&

-Neysi, S., Mazraeh, S. \& Mousavi, Z. (2012). The Importance of Intellectual Capital Disclosure. International Journal of Business and Social Science, 3 (15), 307-310.

-Ng, A. (2006). Reporting intellectual capital flow in technology-based companies: Case studies of Canadian wireless technology companies. Journal of Intellectual Capital, 7 (4), 492-510.

-Nielsen, Christian \& Madsen, Mona Toft (2009). Discourses of Transparency in the Intellectual Capital Reporting Debate: Moving From Generic Reporting Models to Management Defined Information. Critical Perspectives on Accounting, 20 (2009), PP. 847854.

-Nimtrakoon, S. (2015). The relationship between intellectual capital, firms' market value and financial performance: Empirical evidence from the ASEAN. Journal of Intellectual Capital, 16 (3), 587-618.

-Oliveras, E., Gowthorpe, C., Kasperskaya, C. \& Perramon, J. (2008). Reporting intellectual capital in Spain. Corporate Communications: An International Journal, 13 (2), 168-181.

-Orens, R., Aerts, W. \& Lybaert, N. (2009). Intellectual capital disclosure, cost of finance and firm value. Management Decision, 47 (10), 1536-1554. 
-Phusavat, K., Comepa, N., Sitko-Lutek, A. and Ooi, K.B. (2011). Interrelationships between intellectual capital and performance: empirical examination. Industrial Management \& Data Systems, 111 (6), 810-829.

-Rodriguez-Ruiz, O. \& Fernandez-Menendez, J. (2009). Intellectual capital revisited: A citation analysis of ten years of research in the area (1997-2007). Management Research: Journal of the Iberoamerican Academy of Management, 7 (3), 203-219.

-Seleim, A. \& Bontis, N. (2004). Intellectual capital in Egyptian software firms. The Learning Organization, 11 (4/5), 332-346.

-Sharabati, A., Jawad, S. \& Bontis, N. (2010). Intellectual capital and business performance in the pharmaceutical sector of Jordan. Management Decision, 48 (1), 105-131.

-Taliyang, S. \& Jusop, M. (2011). Intellectual capital disclosure and corporate governance structure: Evidence in Malaysia. International Journal of Business and Management, 6 (12), 109-117.

-Tan, H., Plowman, D. \& Hancock, P. (2007). Intellectual capital and financial returns of companies. Journal of Intellectual Capital, 8 (1), 76-95.

-Tseng, KA., Lin , CI. \& Yen, SW. (2015). Contingencies of intellectual capitals and financial capital on value creation: Moderation of business cycles. Journal of Intellectual Capital, 16 (1), 156-173.

-Wang, J. (2008). Investigating market value and intellectual capital for S\&P500. Journal of Intellectual Capital, 9 (4), 546-563.

-Wang, W. Y. \& Chang, C. (2005). Intellectual capital and performance in causal models: Evidence from the information technology industry in Taiwan. Journal of Intellectual Capital, 6 (2), 222-236.

-Williams, R. (2015). Heteroskedasticity and weighted least squares. University of Notre Dame . Available online on, http://www3.nd.edu

-Zeghal, D. \& Maaloul, A (2010). Analyzing Value Added as an Indicator of Intellectual Capital and its Consequences on Company Performance. Journal of Intellectual Capital, 11(1), PP. 39-60. 